\title{
The Production of Sorbitol by Permeabilized and Immobilized Cells of $Z$. mobilis in Sucrose
}

\author{
Josiane Alessandra Vignoli ${ }^{*}$, Maria Antonia Colabone Celligoi ${ }^{2}$, Rui Sérgio Ferreira da \\ Silva ${ }^{3}$ and Márcio de Barros ${ }^{4}$ \\ ${ }^{1,3}$ Departamento de Tecnologia de Alimentos e Medicamentos; Centro de Ciências Agrárias; ${ }^{2,4}$ Departamento de \\ Bioquímica; Centro de Ciências Exatas; Universidade Estadual de Londrina; Londrina - PR - Brasil
}

\begin{abstract}
The production of sorbitol by permeabilized and immobilized cells of Zymomonas mobilis in Luffa cylindrica was investigated in sucrose medium. A full $2^{3}$ factorial design was used to verify the influence of each factor and its interactions. The cell permeabilization showed a significant and negative effect upon the production of sorbitol, while the time of cultivation and the immobilization process were significant and positive. The results demonstrated that the cell immobilization and the time of cultivation of $36 \mathrm{~h}$ presented higher production of sorbitol.
\end{abstract}

Key words: Permeabilization, immobilization, sucrose, Z. mobilis

\section{INTRODUCTION}

The production of sorbitol and gluconic acid from fructose and glucose, respectively, by the glucosefructose-oxidorredutase enzyme (GFOR) present in Z. mobilis periplasm has been greatly explored. $Z$. mobilis metabolizes sucrose, glucose, and fructose by means of Entner Doudoroff pathway, where the gluconic acid produced is transformed into ethanol by the gluconalactonase enzyme. The methodology of cell permeabilization has been explored in the sense of an increase of sorbitol production and gluconic acid, preventing the formation of ethanol. According to Chun and Rogers (1998), the permeabilization process by surfactants or other components alters the membrane permeability, allowing small compounds, such as metallic ions and cofactors to diffuse out of the cells, hence the pathway from gluconate to ethanol become not functional. Then, such procedure would avoid the formation of ethanol, not having a reduction effect upon the production of sorbitol and gluconic acid, since GFOR enzyme has the cofactor firmly linked to it. The concentrated cell mass may be treated with permeabilizing agents such as toluene (Chun and Rogers 1988) or detergents (Rehr et al., 1991). When free cells were permeabilized with toluene, the yield of sorbitol and gluconic acid were 94 and 95\%, respectively; and when the cells were treated with detergent, the yields were 98 and 99\%, respectively, in batch process. Several studies on the production of sorbitol and gluconic acid by $Z$. mobilis were carried out using equimolar mixture of fructose and glucose, which were directly consumed by GFOR (Jang, Parker, Chun 1992; Roh, Kim 1992; Rehr et al., 1991). Z. mobilis also metabolizes sucrose, a substrate of less value than glucose and fructose, however, little is known about the utilization of cells permeabilized in medium based on sucrose.

\footnotetext{
*Author for correspondence
} 
The present work aimed at evaluating the production of sorbitol by cells of $Z$. mobilis permeabilizedwith cetylmethylammoniumbromide (CTAB), in sucrose, in a batch process. In addition to the process of permeabilization, assays were also carried out in which the cells were permeabilized and immobilized in Luffa cylindrica.

\section{MATERIAL AND METHODS}

\section{Microorganism and culture conditions}

Zymomonas mobilis ATCC 29191 was cultivated in medium containing $(\mathrm{g} / \mathrm{L})$ sucrose $(100)$, yeast extract (10); $\quad\left(\mathrm{NH}_{4}\right)_{2} \mathrm{SO}_{4}(1) ; \quad \mathrm{KH}_{2} \mathrm{PO}_{4} \quad$ (2); $\mathrm{MgSO}_{4} .7 \mathrm{H}_{2} \mathrm{O}$ (0.5); $\mathrm{FeSO}_{4}$ (0.5); Peptone (5.). After a $20 \mathrm{~h}$ period (exponential phase) the cells were centrifuged at $7000 \mathrm{rpm}$ for immobilization.

\section{Chemicals}

Cetylmethylammoniumbromide (CTAB) was purchased from Sigma; Chitosan flakes was from Aldrich; glutaraldehyde (70\% in water) was from Sigma. Sponge(Luffa cylindrica) was obtained locally.

\section{Preparation of permeabilized cells and glutaraldehyde cross-linking}

The cells were slowly agitated with CTAB $0.2 \%$ $(\mathrm{v} / \mathrm{v})$ at $4^{\circ} \mathrm{C}$ for ten minutes in $0.1 \mathrm{~N}$ saline solution $(\mathrm{NaCl})$ (Jang et al. 1992). Later, they were centrifuged and washed twice in the same solution. To prevent enzyme loss through the permeabilized cells, a treatment with glutaraldehyde was carried out. The permeabilized and washed cells were suspended in glutaraldehyde $(0.3 \% \mathrm{v} / \mathrm{v})$ in $0.1 \mathrm{M}$ and $\mathrm{pH} 6.2$ potassium phosphate buffer, under agitation at $4^{\circ} \mathrm{C}$ for ten minutes. Such suspension was then centrifuged at 4,000 rpm, for $5 \mathrm{~min}$, and washed twice with the same buffer. For the assays with immobilized cells, the cells were permeabilized and flocculated before the immobilization process.

\section{Cell immobilization}

A cell suspension was obtained by culture in the fermentation medium and re-suspension in $0.85 \%$ saline. Then, chitosan solution was added (1\% chitosan in $2 \%$ acetic acid (v/v)) in a quantity where $10 \mathrm{mg}$ chitosan/g cell was obtained (Ogbonna et al. 1996). The suspension rested for one hour and the optical density of the suspension was read. The efficiency of the flocculation was expressed as percentage of reduction in the optical density and calculated as (A-B/A) x 100; where A was the optical density reading before the addition of chitosan and B, the optical density reading after addition of chitosan and one hour rest. Optical density was read at $605 \mathrm{~nm}$.

The loofa sponge was reduced to $5 \mathrm{~cm} \times 5 \mathrm{~cm}$ pieces to be used as a support. They were autoclaved in water and five pieces were per erlenmeyer in each immobilization experiment. These were inoculated with $2 \mathrm{~g} / \mathrm{L}$ flocculated cells, with later agitation in saline for 30 minutes. After agitation the loofa sponge pieces containing only the cells that adhered were transferred to the culture medium. The quantity of cells that adhered was determined by the difference between the initial concentration $(2 \mathrm{~g} / \mathrm{L})$ and the cell concentration remaining in the recipients (not adhered) where the pieces of loofa sponge had been agitated. The cell concentration was determined by optical density at $605 \mathrm{~nm}$. In the cultures with free cells, a quantity of cells was inoculated equal to that adhered to the supports. The experiments were performed in bath fermentation.

\section{Factorial Design}

A full $2^{3}$ factorial design was used with 8 assays, carried out in random order and in duplicate. The influence of the variables, permeabilization, cultivation time, and immobilization in the production of sorbitol were studied. Table 1 presents the factorial design with the variables tested.

The results were analyzed by Statistic applicative 5.1 (Experimental Design). The goal was to verify which factors were statistically significant, particularly those referring to main effects.

\section{The development of the fermentative process}

The assays were carried out in batch fermentation, in $100 \mathrm{~mL}$ Erlenmeyer flasks of sucrose medium at $300 \mathrm{~g} / \mathrm{L}$ at $30^{\circ} \mathrm{C}$.. After 12 and $36-\mathrm{h}$ the samples were centrifuged.and sugar consumption and the sorbitol produced were determined in supernatant.

\section{Analytical Determinations}

Reducing sugars and total sugars were quantified by Somogy (1952) \& Nelson (1944) methods. Sorbitol was determined by high performance liquid chromatography with a Shim-Pack Aminex-CLC-NH2 (30cm, $1.6 \mathrm{~cm}$ id) column, kept 
in oven at $55^{\circ} \mathrm{C}$, using ultra-pure water with mobile phase at a $1 \mathrm{~mL} / \mathrm{min}$ outflow. A Refraction Index detector was used.

\section{RESULTS AND DISCUSSION}

Tables 2 and 3 present the assay results and the estimated effects related to each factor.

Table $1-2^{3}$ Factorial Design_for the production of sorbitol by Z. mobilis.

\begin{tabular}{r|c|c|c|c|c}
\hline \multicolumn{3}{c}{ Coded variables } & \multicolumn{3}{c}{ Original variables } \\
\hline X1 & X2 & X3 & Cells & Fermentative Process & Time (h) \\
\hline-1 & -1 & -1 & No permabilized & Free & 12 \\
1 & -1 & -1 & Permabilized & Free & 12 \\
-1 & 1 & -1 & No permabilized & Imobilized & 12 \\
1 & 1 & -1 & Permabilized & Imobilized & 12 \\
-1 & -1 & 1 & No permabilized & Free & 36 \\
1 & -1 & 1 & Permabilized & Free & 36 \\
-1 & 1 & 1 & No permabilized & Imobilized & 36 \\
1 & 1 & 1 & Permabilized & Imobilized & 36 \\
\hline
\end{tabular}

Table 2 - Sugar consumption, sorbitol production, and kinetic parameters obtained by Zymomonas mobilis cells at $300 \mathrm{~g} / \mathrm{L}$ sucrose.

\begin{tabular}{ccccccc}
\hline Experiments & Cells & Process & Time $(\mathbf{h})$ & TRS consumed (\%) & Sorbitol (g/L) & $\begin{array}{c}\text { Productivity } \\
\left(\mathbf{g} / \mathbf{L} . \mathbf{h}^{-1}\right)\end{array}$ \\
\hline 1 & $\mathrm{NP}$ & Free & 12 & 20.92 & 12.69 & 1.06 \\
2 & $\mathrm{P}$ & Free & 12 & 18.92 & 19.84 & 1.65 \\
3 & $\mathrm{NP}$ & Imobilized & 12 & 57.05 & 23.72 & 1.98 \\
4 & $\mathrm{P}$ & Imobilized & 12 & 30.28 & 8.03 & 0.67 \\
5 & $\mathrm{NP}$ & Free & 36 & 57.03 & 25.71 & 0.71 \\
6 & $\mathrm{P}$ & Free & 3 & 60.02 & 32.34 & 0.9 \\
7 & $\mathrm{NP}$ & Imobilized & 36 & 55.90 & 49.21 & 1.37 \\
8 & $\mathrm{P}$ & Imobilized & 36 & 67.71 & 19.94 & 0.55 \\
\hline
\end{tabular}

$\mathrm{NP}=$ no permeabilized

$\mathrm{P}=$ permeabilized

TRS $=$ Total reducing sugar

Table 3 - Estimate of the effects related to different factors

\begin{tabular}{lll}
\hline Factor & Effect & p \\
\hline Average & $23.94^{*}$ & $0 * *$ \\
$\mathrm{X}_{1}$ & $-7.80^{*}$ & $0.00005^{* *}$ \\
$\mathrm{X}_{2}$ & $2.58^{*}$ & $0.03^{*}$ \\
$\mathrm{X}_{3}$ & $15.73^{*}$ & $0^{* *}$ \\
$\mathrm{X}_{1} \cdot \mathrm{X}_{2}$ & $-14.69^{*}$ & $0 * *$ \\
$\mathrm{X}_{1} \cdot \mathrm{X}_{3}$ & $-3.52^{*}$ & $0.007^{* *}$ \\
$\mathrm{X}_{2} \cdot \mathrm{X}_{3}$ & $2.97^{*}$ & $0.02^{*}$ \\
\hline
\end{tabular}

$\mathrm{R}^{2}=0,9863$

$\mathrm{X}_{1}=$ Cells (permeabilized or not)

$\mathrm{X}_{2}=$ Process (free or immobilized)

$\mathrm{X}_{3}=$ fermentation time $(12$ e $36 \mathrm{~h})$

$*=$ significant $\mathrm{P}<0,05$ 
Results showed that the three factors $X_{1}, X_{2}$, and $\mathrm{X}_{3}$ were significant for sorbitol production $(\mathrm{g} / \mathrm{L})$ (Table 3).The interaction among all the factors tested presented a significant effect. Evidently, $\mathrm{X}_{1}$ (cell condition) was negative, and the utilization of such variable at high level +1 (permeabilized cells) would cause a decrease in the production of sorbitol. On the other hand, $\mathrm{X}_{2}$ (type of process) and $\mathrm{X}_{3}$ (time) had positive effects on the production of sorbitol, therefore, the utilization of the immobilized process and the increase of time would cause an increase on the levels of sorbitol.

According to the statistical analysis, the effect of cell permeabilization on the production of sorbitol was negative. However, when the assays with free cells were analyzed in an isolated way, permeabilization increase to $56 \%$ in the production of sorbitol in a 12-h cultivation (assays 1 and 2) and of $26 \%$ in 36 hours (assays 5 and 6). Nevertheless, the association of the permeabilization and immobilization process caused severe decrease in the production of sorbitol. In the $12-\mathrm{h}$ time, the production of sorbitol fell from 23.72 to $8.03 \mathrm{~g} / \mathrm{L}$ in immobilized and permeabilized cells; and from 49.21 to 19.94 $\mathrm{g} / \mathrm{L}$ in the 36-h time under the same conditions (Table 2). The results revealed the negative effect of such association upon the formation of sorbitol.

The utilization of permeabilized cells of $Z$. mobilis has been described by several authors (Chun; Rogers, 1998; Rehr et al., 1991; Ferraz et al., 2001); however, in those studies the process of permeabilization was used in media containing glucose and fructose for formation of gluconic acid and sorbitol, respectively by GFOR. Permeabilized Z. mobilis was also used by Wieberg et al. (1997) aiming at an efficient production of gluconate. The production of sorbitol was conducted in equimolar glucosefructose mixture and conversions of substrate into product were obtained at a rate of $97 \%$ in a period of 15 to $20 \mathrm{~h}$. The production of sorbitol and gluconic acid was also carried out with purified glucose-fructose-oxidorredutase of $Z$. mobilis cells. Silva-Martinez et al. (1998) obtained $85 \%$ of substrate conversion in an average time of $25 \mathrm{~h}$. However, the isolated enzyme was unstable during the substrate conversion, presenting a quick inactivation in approximately $5 \mathrm{~h}$ (Nidetzky et al., 1997), whereas, with cells of Z. mobilis, the process remain stable for a longer time. Ferraz et al. (2001) obtained 2.6 sorbitol/g cell $\mathrm{h}^{-1}$ for over $25 \mathrm{~h}$.
Silveira et al. (1999), proposed a batch process to obtain sorbitol and gluconic acid, using nonpermeabilized cells, in which high yields in the bioconversion phase were obtained when the initial glucose plus fructose concentration was increased to $650 \mathrm{~g} / \mathrm{L}$. Considering that the assays carried out here were batch runs and that sucrose was used, the production raises obtained by means of permeabilization could be considered satisfactory. However, the permeabilization and immobilization in Luffa should not be combined. The use of sucrose was also advantageous since it could be obtained from several agroindustrial byproducts. The immobilization in Luffa cylindrica was an important factor to be considered, since it caused a increase in the production with minor costs to the process, being a cheap carrier which did not present problems to be eliminated in the environmental (Ogbonna et al. 1994). The use of permeabilized and immobilized cells could be advantageous considering the simplicity of the bioreactor required for continuous processing. On the other hand, considerable long-term stability of the system must be assured to avoid the need for frequent production of the biocatalyst (Silveira; Jonas, 2002).

\section{CONCLUSION}

The permeabilization process in an isolated way leads to raise the production of sorbitol; however, when it is associated to the immobilization process, significant decreases occur in the obtained production. The cultivation time, within the range studied, had a positive effect to obtain sorbitol. The production of sorbitol by permeabilized cells in sucrose was possible, as though the results obtained were lower than those related for permeabilized and cultivated cells in medium that contained glucose and fructose. The factorial design allowed to develop a model with good predictive capacity within the range tested

\section{ACKNOWLEDGEMENTS}

We acknowledge the financial suport of CAPES. 


\section{RESUMO}

Foi investigado a produção de sorbitol em meio de sacarose por células de $Z$. mobilis permeabilizadas e imobilizadas em Luffa cylindrica. Este trabalho avaliou o efeito da permeabilização de células de Z. mobilis tratadas com cetilmetilamoniobrometo e imobilizadas em Luffa cylindrinca. Um planejamento fatorial completo $2^{3}$ foi utilizado para verificar a influência dos fatores e suas interações. A permeabilização da célula mostrou um efeito significante e negativo sobre a produção de sorbitol, enquanto o tempo de cultivo e o processo de imobilização foram significantes $\mathrm{e}$ positivos. Os resultados mostraram que a imobilização das células e o tempo de cultivo de $36 \mathrm{~h}$ forneceram concentração mais elevadas de sorbitol.

\section{REFERENCES}

Chun, U. H. and Rogers, P. L. (1988), The simultaneous production of sorbitol from fructose and gluconic acid from glucose using an oxidorreductase of Zymomonas mobilis. Applied Microbiology and Biotechnology, 29, 19-24.

Ferraz, H. C.; Alves, T. L. M. and Alves C. P. (2001), Coupling of an electrodialysis unit to a hollow fiber bioreactor for separation of gluconic acid from sorbitol produced by Zymomonas mobilis permeabilized cells. Journal of Membrane Science, 43-51.

Jang, K. H.; Park, C. J. and Chun, U. H. (1992), Improvement of oxidorreductase stability of cethyltrimethylammoniumbromide permeabilized cells of Z. mobilis trough glutardialdehyde crosslinking. Biotechnology Letters, 14, 311-316.

Kim, H. S. (1992), Continuous production of gluconic acid and sorbitol from sucrose using invertase and an oxidoreductase from Z.mobilis. Enzyme Microbial Technology, 13, 920-924.

Nelson, N. (1944), A photometric adaptation of the Somogy method for determination of glucose. Biochemistry, 153, 375-380.

Nidetzky, B.; Fürlinger, M.; Golhofer D.; Scopes, R.; Haltrich, D. and Kulbe, K. (1997), Improved operational stability of cell free glucose-fructoseoxidorreductase from Zymomonas mobilis for the efficient synthesis of sorbitol and gluconic acid in a continuous ultrafiltration membrane reactor. Biotechnology and Bioengineering, 6, 623-629.

Ogbonna et al. (1994), Loofa (Luffa cylindrica) sponge as a carrier for microbial cell immobilization. Journal of Fermentation and Bioengineering, 78, 437-442.
Ogbonna, J. C.; Tomiyama S. and Tanaka H. (1996), Development of a method for immobilization of nonflocculating cells in loofa (Luffa cylindrica) sponge. Process Biochemistry, 31.

Rehr, B.; Wilhem. C. and Sahm, N. (1991), Production of sorbitol and gluconic acid by permeabilized cells of Zymomonas mobilis. Applied Microbiology and Biotechnology, 144-148.

Silva-Martinez, M. et al. (1998), Simultaneous enzimatic synthesis of gluconic acid and sorbitol: continuous process development using glucosefructose-oxidorreductase from Zymomonas mobilis. Applied Biochemistry Biotechnology, 72, 863-868.

Silveira, M. M.; Wisbeck, E.; Lemmel, C.; Erzinger, G. S.; Lopes da Costa, J. P.; Bertasso, M. and Jonas, R. (1999), Bioconversion of glucose and fructose to sorbitol and gluconic acid by untreated cells of Zymomonas mobilis. Journal of Biotechnology, 75, 99-103.

Silveira, M. M. and Jonas, R. (2002), The biotechnological production of sorbitol. Applied Microbiology Biotechnology, 59, 400-408.

Somogy, M. A. (1952), A new reagent for determination of sugar. Journal Biology Chemistry, 160, 61-68.

Wilberg, K. Q.; Alves, T. L. M. and Nobrega, R. (1997), Enzymatic catalysis by permeabilized cells. Brazilian Journal of Chemical Engineering, 14, 347-352.

Received: April 05, 2005; Revised: November 08, 2005; Accepted: April 05, 2006. 